\title{
RESTRICTION OF THE RIGHT TO THE LIBERTY AND SECURITY OF MINORS ACCORDING TO THE INTERNATIONAL AND NATIONAL LAW (BY THE EXAMPLE OF THE RUSSIAN FEDERATION)
}

Gulnara R. Shaihutdinova ${ }^{1}$ Gulshat Z. Shamilova ${ }^{2}$

\begin{abstract}
The article is about the main points of the minors arrest and detention who are suspected in a criminal offense under paragraph $5(\mathrm{~d})$ of Article 5 of the Convention for the Protection of Human Rights and Fundamental Freedoms of 1950; the legality of the minors arrest and detention, rights and freedoms. The special attention is paid to the study of the pointed legal positions of the European Court of Human Rights. The importance of the study is connected with the fact that the right to the liberty and security is one of the most important rights included in the list of internationally recognized human rights and freedoms. From the point of the generally accepted classification in the law theory and Russian constitutional law, as well as in the theory of international law, the analysing law
\end{abstract}

belongs to the civil (personal) rights. In this regard, the right to the liberty and security can be characterized as a law that has a natural character and it is closely connected with the nature of man.Detention or arrest is the most severe measure; it is applied only on the basis of a court decision which is based only on the results of consideration which is accepted as a result of the court's learning of the relevant petition submitted by an investigator or inquiry officer.

Keywords: arrest, detention, rights to liberty and security of person, crime, a minor, European Convention for the Protection of Human Rights and Fundamental Freedoms of 1950, European Court of Human Rights.

\footnotetext{
${ }^{1}$ Kazan Federal University. Email: ildar_sh@mail.ru, Tel: 8926768500.

${ }^{2}$ Kazan Federal University. Email: gulshatik-s@1ist.ru. Tel:89274303536.
} 


\section{Introduction}

The right to liberty and personal security $^{3}$ is an inalienable right for every person; it determines the existence of constitutional guarantees for the protection and security of the personal dignity, the prohibition of torture, violence, other cruel or degrading treatment or punishment (Articles 17, 21 and 22 of the Constitution of the Russian Federation $)^{4}$. Restriction of this right is allowed only according to the Constitution of the Russian Federation; it is carried out in the manner prescribed by law, in compliance with general legal principles and on the basis of necessity criteria, reasonableness and proportionality, with no touch of the very essence of this right .

Coercive measures restricting freedom and personal inviolability, that is important to isolate a person from society and his/her stay in a closed space, are provided for the legislation on administrative offenses, criminal,

\footnotetext{
3 The word "security" ("right to liberty and security of person") is used in the translation in official Russian as the concept of "inviolability"; the authors of the paper consider this right within the translation as "security"

${ }^{4}$ Resolution of the Supreme Court Plenum of the Russian Federation dated December 25,
}

criminal procedural, and criminal executive law, other federal laws and are including delivery, drive, escort, transfer (sending) of a convicted person to another correctional institution, other transfer, for example, to places of detention for investigative actions or court hearings or in medical organizations, as well as administrative detention, administrative arrest, disciplinary arrest, placement in a special institution of a foreign citizen (stateless person) subject to administrative expulsion from the Russian Federation, deportation or readmission, placement of a minor in a temporary detention centre for juvenile delinquents of an internal affairs or in a special closed-type educational institution, detention, remand in custody and ward, arrest, imprisonment.

Therefore, the application of criminal and criminal procedural law in the course of pre-trial and trial of criminal cases and materials in relation to juvenile offenders must comply with

2018 No. 47 "On some issues that the courts have in considering administrative cases related to violation of the conditions of detention for persons in places of detention", "Rossiyskaya Gazeta”, dated January 10, 2019 No. 2, Bulletin of the Supreme Court of the Russian Federation, February 2019, No. 2 
the generally recognized principles and norms of international law, international treaties to protect the rights and legitimate interests of minors in the exercise of criminal, criminal-procedural and criminal-executive proceedings, as well as implement other procedures prescribed by law aimed to prevent juvenile delinquency and increase preventative impact of litigation.

\section{Methods}

Within this work, we will use the following methods: analysis, synthesis, general scientific methods: the deductive method, and also particular scientific methods: the historical and legal method, the method of legal forecasting.

\section{Results and Discussion}

Minors must be deprived of their liberty in accordance with the principles and procedures set in the United Nations Rules for the Protection of Juveniles Deprived of their Liberty

\footnotetext{
${ }^{5}$ Rules of the United Nations on the Protection of Juveniles Deprived of their Liberty (Havana Rules) adopted by the Resolution of the United Nations General Assembly on December 14, 1990 N 45/113.

6 The problem of juvenile delinquency has a special place in the work of law enforcement agencies in all developed countries. Effective
}

(Havana Rules) adopted by the United Nations General Assembly Resolution dated December 14, 1990 No. 45/111 and in the Standard Minimum rules of the United Nations for the administration of juvenile justice (the Beijing rules) . $^{5}$. The minors' deprivation of liberty should be applied as an urgent measure and during the minimum necessary period of time. The term of punishment shall be determined by the judicial authority, not excluding the possibility of his or her early release ${ }^{6}$.

The international community has approved and adopted a number of documents relating to fundamentally important issues on the field of ensuring the rights of a child, the prevention of juvenile delinquency, the organization of justice for them, the conditions for the treatment of juvenile offenders. This code of international law actually formed the rules for the treatment of juveniles committing offenses ${ }^{7}$. An important principle of international law which is adopted by the international community

criminal law measures applied to adolescents can help prevent their offenses and at the same time ensure their correction

${ }^{7}$ The international legal framework for the criminal law policy regarding juvenile offenders (S. I. Martynova,"Advokat" ("Lawyer"), N 12, December 2010) 
is to ensure the flexible application of criminal law against minors. Thus, Article 6.1 of the Beijing Rules states that an appropriate amount of discretion should be provided at all stages of the court and at various levels of juvenile justice, including in the investigation, trial, court decision and enforcement court decisions $^{8}$. Thus, the international legal acts concerning the administration of juvenile justice are very humane and the detention of juveniles before trial is used only as a last resort and for the shortest possible time.

International legal acts should serve as the main component to regulate the framework of the Russian criminal law policy regarding juvenile offenders ${ }^{9}$.

The Convention, being a special highly significant self-executing international treaty of the Russian Federation, has become an integral part of the legal system of Russia ${ }^{10}$.

The European Convention provides four groups of circumstances

\footnotetext{
${ }^{8}$ UN Standard Minimum Rules for the Administration of Juvenile Justice (Beijing Rules) adopted by UN General Assembly Resolution 40/33 dated November 29, 1985

${ }^{9}$ Generally accepted international principles and standards for the administration of juvenile justice are to be integrated into national law and practice
}

that make lawful the deprivation of the liberty; they lie outside the framework of the criminal process, although they may be connected with it by some of its features. This group includes paragraph "d", part 1, Article 5 of the Convention, which we will consider below.

Paragraph “d”, part 1, Article 5

of the Convention for the Protection of Human Rights and Fundamental Freedoms reads: "1... No one may be deprived of their liberty except for in the following cases and in accordance with the procedure established by law... d) the detention of a minor on the basis of a lawful order for educational supervision or their lawful detention in order to be brought before a competent law enforcement body... ".

The term "minor" refers to persons under the age of $18^{11}$, according to the European standards and Resolution CM (72) by the Committee of Ministers of the European Council ${ }^{12}$. Paragraph "d" allows not only the

\footnotetext{
${ }^{10}$ By the Federal Law No. 54 dated March 30, 1998, the Russian Federation ratified the European Convention for the Protection of Human Rights and Fundamental Freedoms, as amended (hereinafter - the Convention, the European Convention)

${ }^{11}$ Koniarska v. the United Kingdom (dec.)

${ }^{12} \mathrm{X}$. v.Switzerland, Commission Decision dated December 14, 1979
} 
deprivation of liberty of minors; it contains specific, but not exhaustive examples of circumstances in which a minor can be deprived of liberty, namely for the purpose of: a) educational supervision of this person; or b) delivering it to a competent judicial authority ${ }^{13}$.

The first part of paragraph "d", part 1, Article 5 of the Convention permits deprivation of liberty based on a decision of a court or administrative authority to ensure that a child visits an educational institution. In the context of the detention of minors, the term "educational supervision" should not be reduced only to classroom learning. Such oversight should cover many aspects of the exercise, in accordance with the authority, of parental rights for the interests and protection of the person concerned ${ }^{14}$. Paragraph "d" does not prevent the application of temporary detention measures pending the establishment of an educational supervision regime without the use of educational supervision itself. In such circumstances, however, the mentioned

\footnotetext{
${ }^{13}$ Mubilanzila Mayeka and Kaniki Mitunga v. Belgium, $§ 100$

${ }^{14}$ P. and S. v. Poland, $\S 147$; Ichin and Others v. Ukraine, § 39; D.G. v. Ireland, § 80
}

regime should be established as soon as possible after imprisonment in the appropriate institution (open or closed) and with resources sufficient to achieve this $\operatorname{aim}^{15}$. If the state has chosen a system of educational supervision with deprivation of liberty, it is obliged to provide the appropriate institutions that would satisfy the safety and education requirements of this system in order to ensure compliance with the requirements of paragraph 5 (d), Article 5 of the Convention $^{16}$. The court does not find that the institution for the detention of minors in corresponds to the concept of "educational supervision" if educational activity is not carried out in it ${ }^{17}$.

So, in the Resolution of the ECHR in the case of "Blokhin $\mathrm{v}$. Russia," there was established a violation of paragraphs 1 and 3 (subps. c and b ), Article 6, par. 1 of Article 5, and Article 3 of the Convention in connection with the violation of due process in relation to a minor 12-year-old I.B. Blokhin, while conducting an investigation on a report of a crime committed by him and considering by a

\footnotetext{
${ }^{15}$ Bouamar v. Belgium, $§ 50$

${ }^{16}$ A. and Others v. Bulgaria, § 69; D.G. v. Ireland, § 79

${ }^{17}$ Ichin and Others v. Ukraine, § 39
} 
court of the issue of his placement in a temporary detention centre for juvenile offenders (hereinafter referred to as the Centre) and illegal detention of the applicant in the Centre. The ECHR indicated that the applicant's placement in the Centre was equivalent to imprisonment, since the Centre was closed and guarded, a disciplinary regime was applied to those who were in it; personal things were confiscated, etc. Since the national authorities did not mention any specific offense, from which it was necessary to deter the applicant, as well as taking into account that the applicant was not found guilty of an offense because he did not reach the age of criminal responsibility, the applicant's report was unlawful. The ECHR explained that starting from the moment a child's detention by enforcement agencies he or she must be guaranteed at least the same rights and guarantees as adults.

The second part of paragraph $\mathrm{d}$, part 1, Article 5 of the Convention governs the lawful detention of a minor so that he or she is brought before a competent law enforcement agency.

\footnotetext{
${ }^{18}$ X. v. Switzerland, Commission Decision dated December 14, 1979
}

According to the preparatory work, this provision was aimed at resolving issues of the detention of minors before the start of civil or administrative proceedings, and the detention in connection with criminal proceedings was supposed to be made the subject of paragraph "c", part 1, Article 5 of the Convention.

However, the detention of a minor accused in committing a crime while preparing a psychiatric report necessary to decide on his/her mental state was recognized as falling under paragraph 5 (d), Article 5 of the Convention as detention so that the minor would appear before the competent authority ${ }^{18}$. With regard to paragraph "d", part 1, article 5 of the Convention, the ECHR proceeds from the fact that it is advisable not to apply to minors ordinary coercive measures designed for adults, and to carry out socially oriented justice with a less formal procedure. So, it was found unacceptable to place a minor in a pretrial detention centre together with adults; any detention of a teenager should go into a regime working under his/her re-education is possible ${ }^{19}$.

\footnotetext{
${ }^{19}$ Following the resolution by the ECHR of the case of Buamar v. Belgium in 1988, the Law of February 2, 1994 was passed in Belgium, which
} 


\section{Summary}

Russian legislation basically correlates with the Convention in such moments as it speaks of the permissibility of detention of a minor for educational supervision and the detention necessary for a teenager to appear before a competent authority. But it is subject to compliance with the Convention in a number of other provisions $^{20}$ :

1) Ensuring that trials involving minors are proceeded in urgency, avoiding excessive delays in order to ensure an effective educational process;

2) Strengthening the legal position of minors in the course of the proceedings, including the investigation, recognizing inter alia ${ }^{21}$ :

- Presumption of innocence;

- The right for the assistance of a lawyer, who can be officially appointed and paid by the state if it is necessary;

- The right to the presence of parents or another legal representative

prohibited the juvenile court from re-placing the teenager in one trial.The deadline for such a conclusion may not exceed fifteen days. See: Glotov S.A., Petrenko E.G. Human rights and their protection in the European Court. Krasnodar: Publ."Yug", 2000, p.113

${ }^{20}$ In particular, in the judgment of the European Court of Human Rights of March 23, 2016The who must be informed about the case from the moment it occurs;

- The right of minors to call and interrogate witnesses to confront them;

- The right to file a complaint;

- The right for the petition to review the imposed sentence.

\section{Conclusions}

Having analysed the current situation in the Russian legislation and the provisions of the ECHR, we come to the following conclusions:

1) Some measures of reeducation of adolescents who have committed criminal acts are indicated in the Criminal Code of the Russian Federation, although they are not criminal penalties by their nature;

2) Criminal cases ending in the appointment of educational measures or medical and educational measures for adolescents are considered in the framework of the general judicial procedure, which is also used to convict

Blokhin v. Russian Federation case (Complaint No. 47152/06, Grand Chamber) recommends that the authorities of the Member States review their legislation and practice, if necessary, in order to apply it

${ }^{21}$ Inter alia (lat.) - among other things, in particular 
adults. There are no juvenile courts in the

Russian Federation

3) The juvenile commissions have the right to send minors to special educational institution to deprive them of their freedom which is against the Convention;

4) While the commission for juvenile affairs considering materials minors cannot use the right to have a defence counsel;

5) The conditions of stay of minors in educational and medical institutions, in the context of the Convention, are imprisonment with all the legal consequences arising from this.

\section{Acknowledgments}

The work is performed according to the Russian Government Program of Competitive Growth of Kazan Federal University.

\section{References}

The word "security" ("right to liberty and security of person") is used in the translation in official Russian as the concept of "inviolability"; the authors of the paper consider this right within the translation as "security"
Resolution of the Supreme Court Plenum of the Russian Federation dated December 25, 2018 No. 47 “On some issues that the courts have in considering administrative cases related to violation of the conditions of detention for persons in places of detention", "Rossiyskaya Gazeta”, dated January 10, 2019 No. 2, Bulletin of the Supreme Court of the Russian Federation, February 2019, No. 2

UN Rules for the Protection of Juveniles Deprived of their Liberty (Havana Rules) adopted by the United Nations General Assembly dated December 14, 1990 No. $45 / 113$

The problem of juvenile delinquency has a special place in the work of law enforcement agencies in all developed countries. Effective criminal law measures applied to adolescents can help prevent their offenses and at the same time ensure their correction.

The international legal framework for the criminal law policy regarding juvenile offenders (S. I. Martynova, 
Periódico do Núcleo de Estudos e Pesquisas sobre Gênero e Direito

Centro de Ciências Jurídicas - Universidade Federal da Paraíba V. 8 - No 06 - Ano 2019 - Special Edition ISSN | 2179-7137 | http://periodicos.ufpb.br/ojs2/index.php/ged/index

"Advokat" ("Lawyer"), No. 12,

December 2010)

Ichin and Others v.Ukraine, $\S 39$

United Nations Standard Minimum

Rules for the Administration of Juvenile

Justice (Beijing Rules) adopted by UN

General Assembly Resolution 40/33

dated November 29, 1985

Generally accepted international principles and standards for the administration of juvenile justice.

Federal Law No. 54 daed March 30, 1998.

Koniarska v. the United Kingdom (dec.)

X. v.Switzerland, Commission Decision

dated December 14, 1979

${ }^{[12]}$ Mubilanzila Mayeka and Kaniki

Mitunga v.Belgium, $\S 100$

P. and S. v.Poland, § 147; Ichin and Others v.Ukraine, §39; DG v. Ireland, § 80

Bouamar v.Belgium, $§ 50$

A. and Others v.Bulgaria, §69; DG v.

Ireland, $§ 79$
X. v.Switzerland, Commission Decision dated December 14, 1979

Glotov S.A., Petrenko E.G. Human rights and their protection in the European Court. - Krasnodar: Publ. House "Yug", 2000, p.113.

Resolution of the European Court of Human Rights on March 23, 2016. The Case "Blokhin v. Russia" (Complaint No. 47152/06, Grand Chambe 